\title{
ПСИХОЛОГІЧНА СУТНІСТЬ ТА МОТИВИ ПРОСОЦАЛЬНОЇ ПОВЕДІНКИ ОСОБИСТОСТІ
}

\author{
Дерев'янко Наталія
}

Рівненський державний гуманітарний університет, м. Рівне, Україна, rudka.natali@ukr.net, ORCID iD: 0000-0001-6712-6474

У статті проаналізовано основні теоретичні підходи щодо розуміння просоціальної поведінки. Здійснено аналіз теоретичних та емпіричних досліджень із порушеної проблеми й розглянуто основні мотиви виконання просоціальних дій.

Мета статті - здійснити теоретичний аналіз сутності та мотивів просоціальної поведінки особистості.

Методи дослідження. У дослідженні використано такі теоретичні методи наукового пошуку, як аналіз, узагальнення, систематизація наукової літератури 3 питань вивчення просоціальної поведінки та мотивації до вчинення просоціальних дій.

Результати. Просоціальність передбачає будь-який вид допомоги на користь іншої людини чи соціальної спільноти. Вона передбачає соціальну взаємодію й характеризує особистість як соціально зрілу, спроможну діяти на користь суспільних інтересів. У психологічній теорії існує декілька моделей, які пояснюють, які типи мотивів впливають на вчинення просоціальних дій. Ними є модель полегшення негативного стану, моделі витрат та винагороди й емпатійноальтруїстична.

Висновки. Основною характеристикою просоціальної поведінки є іiї соціальна адаптованість, що виявляється в реалізації дій на благо інших. Просоціальна поведінка забезпечує розвиток суспільства, а також $є$ ефективним способом впливу та управління соціальними масами. Одним із найбільш нерозв'язаних проблем просоціальної поведінки $€$ вивчення мотивів, що спонукають особистість виконувати відповідні дії.

Визначено три групи мотивів реалізації просоціальної поведінки. До першої віднесено альтруїстичні мотиви (виконання просоціальної дії на благо інших без отримання вигоди, так звана «чиста допомога»). До другої групи належать егоїстичні мотиви, тобто ті, що передбачають вигоду для допомагаючого. Ними можуть бути внутрішні мотиви: мотив усунення психологічного дискомфорту, мотив отримання позитивних емоцій, мотиви самозаохочення й самоповаги тощо; та зовнішні, наприклад мотив соціального визнання. До третьої групи віднесено соціальні мотиви, тобто ті, які $є$ загальноприйнятими в суспільстві й певним чином здійснюють певний соціальний тиск щодо виконання просоціальних дій. Це релігійні та морально-етичні (милосердя, патріотизм) мотиви.

Ключові слова: просоціальність, допомога, альтруїзм, мотиви, соціум.

ISSN 2308-3743 (Online), ISSN 2227-1376 (Print)

(C) Дерев'янко Н., 2020. Ця стаття відкритого доступу на умовах CC BY-NC 4.0 
Derevyanko Natalia. Psychological Essence and Motives of Prosocial Behavior of Personality. The article analyzes the main theoretical approaches to understanding prosocial behavior. The author analyzes the theoretical and empirical researches of the problem and considers the main motives of prosocial action.

The purpose of the article is to carry out a theoretical analysis of the essence and motives of prosocial behavior of the individual.

Research Methods. The following theoretical methods of scientific research were used in the research: analysis, generalization, systematization of scientific literature on the study of prosocial behavior and motivation to perform prosocial actions.

Results. Prosociality involves any kind of assistance for the benefit of another person or social community. It presupposes social interaction and characterizes the individual as a social slice capable of acting in the public interest. In psychological theory, there are several theories that explain what types of motives influence the commission of prosocial actions. These are the negative relief model, the cost-reward model, and the empathic-altruistic model.

Conclusions. The main characteristic of prosocial behavior is its social adaptability, which is manifested in actions for the benefit of others. Prosocial behavior ensures the development of society, and is also an effective way to influence and manage the social masses. One of the most unresolved problems of prosocial behavior is the study of motives that motivate individuals to take helpful actions.

The author identifies three groups of motives for prosocial behavior. The first group includes altruistic motives (the implementation of prosocial action for the benefit of others without benefit, the so-called «pure help»). The second group includes selfish motives, the motives that provide benefits for the helper. They can be internal motives: the motive of eliminating psychological discomfort, the motive of receiving positive emotions, the motive of self-encouragement and self-respect, etc.; and external motives, such as the motive of social recognition. The third group includes social motives, those that are generally accepted in society and in some way create a certain social pressure to carry out prosocial actions. These are religious and moral-ethical (mercy, patriotism) motives.

Key words: prosociality, help, altruism, motives, society.

Дерев'янко Наталья. Психологическая сущность и мотивы просоциального поведения личности. В статье анализируются основные теоретические подходы к пониманию просоциального поведения. Проводится анализ теоретических и эмпирических исследований по затронутой проблеме и рассматриваются основные мотивы осуществления просоциальных действий.

Цель статьи - осуществить теоретический анализ сущности и мотивов просоциального поведения личности.

Методы исследования. В исследовании используются следующие теоретические методы научного поиска: анализ, обобщение, систематизация научной литературы по изучению просоциального поведения и мотивации к совершению просоциальных действий. 
Pезультаты. Просоциальность предусматривает любой вид помощи в пользу другого человека или социальной общности. Она предусматривает социальное взаимодействие и характеризует личность как социально зрелую, способную действовать в пользу общественных интересов. В психологии существует несколько теорий, объясняющих, какие типы мотивов влияют на совершение просоциальных действий. Ими являются модель облегчения негативного состояния, модели затрат и вознаграждения и емпатийно-альтруистическая.

Bbыводы. Основной характеристикой просоциального поведения является ее социальная адаптация, проявляющаяся в осуществлении действий на благо других. Просоциальное поведение обеспечивает развитие общества, а также является эффективным способом воздействия и управления социальными массами. Одной из нерешенных проблем о просоциальном поведении является изучение мотивов, побуждающих личность осуществлять помогающие действия.

Определяются три группы мотивов совершения просоциального поведения. К первой относятся альтруистические (осуществление просоциального действия на благо других без получения выгоды, так называемая «чистая помощь»), ко второй - эгоистические мотивы, то есть те, что предусматривают выгоду для помогающего. Ими могут быть внутренние мотивы: мотив устранения психологического дискомфорта, мотив получения положительных эмоций, мотивы самопоощрения и самоуважения и т. п.; и внешние мотивы, например мотив социального признания. К третьей группе принадлежат социальные мотивы, то есть те, которые есть общепринятыми в обществе и определенным образом создают определенное социальное давление по осуществлению просоциальных действий. Это религиозные и морально-этические (милосердие, патриотизм) мотивы.

Ключевые слова: просоциальность, помощь, альтруизм, мотивы, социум.

Постановка наукової проблеми. Дослідження мотивів того, чому одні люди допомагають іншим, завжди було в полі уваги гуманітарних досліджень, а саме: філософії, педагогіки та психології. Природа людини багатогранна й неоднозначна одночасно, люди часто діють на користь іншим, і ці вчинки є зразками просоціальної поведінки. Вона має різні прояви: допомога людині, яка іiі потребує; обмін особистими ресурсами; досвід волонтерства; співпраця 3 іншими людьми для досягнення якихось спільних цілей тощо. Основну увагу наукових досліджень зосереджено на допомозі (просоціальні дії - ситуація, коли одна людина потребує, а інша надає необхідну допомогу для усунення потреби іншого).

Після різкого зростання досліджень просоціальної поведінки 3 кінця 1970-х, приблизно на початку 1990-х рр., простежено помітне 
зниження досліджень на цю тему протягом більше десяти років. Однак останнім часом відновився інтерес до просоціальної поведінки та емоцій. Новітнє покоління досліджень у деяких аспектах сильніше за інші. Багато концептуальних питань не було належно обговорено або вирішено, і численні питання щодо просоціальної поведінки залишаються без відповіді (Eisenberg, Spinrad, 2014).

Отже, збільшення досліджень із проблеми просоціальної поведінки, переосмислення концептуальних основ просоціальності, удосконалення діагностичного інструментарію, а також систематична зміна суспільних поглядів та соціальної комунікації визначають необхідність постійного оновлення інформації щодо сутності, мотивів й особливостей розвитку просоціальної поведінки особистості.

Аналіз останніх досліджень із цієї проблеми. Дослідження просоціальної поведінки здійснюються в закордонній і вітчизняній психологічній практиці. Так, зазначену проблему вивчали К. Абульханова-Славська, Н. Корчакова, О. Леонтьєв, Р. Павелків, С. Рубінштейн, С. Ільїн, Н. Молчанова, М. Наконечна, О. Киричук, Дж. Твенге, Ш. Тейлор, В. Занде, Р. Роше Олівар, К. Бетсон, А. Пауелл та ін.

Мета статті - виконати теоретичний аналіз сутності й мотивів просоціальної поведінки особистості.

Методи та методики. У дослідженні використано такі теоретичні методи наукового пошуку, як аналіз, узагальнення, систематизація наукової літератури з питань вивчення просоціальної поведінки й мотивації до вчинення просоціальних дій.

Виклад основного матеріалу й обгрунтування отриманих результатів дослідження. «Психологічний словник» за редакцією В. Войтка визначає просоціальну поведінку як «поведінку індивіда, що орієнтується на благо соціальних груп, надання допомоги. Вона зумовлюється переважно намірами бути корисним іншим і найчастіше проявляється в допомозі, участі чи співпраці, взаємодії, суспільному служінні. Відповідно до цього можуть бути задіяні такі ресурси допомоги ближньому чи суспільству, як увага, час, праця, грошові видатки, відсування на задній план власних бажань і планів, безкорисливе соціальне служіння, самопожертва тощо (Войтко, 1982). Натомість у «Психологічному словнику» I. Кондакова зазначено, що просоціальна поведінка спрямована, передусім, на збереження, захист, полегшення функціонування та розвитку соціальних спільнот (іншої людини, колективу, громадської організації, культурної норми тощо) (Кондаков, 
2007). Зважаючи на це, загалом просоціальність передбачає будьякий вид допомоги на користь іншої людини чи соціальної спільноти.

Просоціальні дії особистості зумовлені соціальною природою людини. Із цього приводу П. Бізін зазначає, що просоціальність - це одна з характеристик соціально адаптованої особистості, що визначається як уміння взаємодіяти 3 іншими членами групи, суспільства задля досягнення результатів, які повністю або частково задовольняють потреби особистості (Бізін, 2019). Соціальна адаптованість особистості проявляється в спроможності ефективно взаємодіяти один 3 одним. За визначенням О. Бойко, просоціальність передбачає здатність відгукнутися на потреби іншого та активно впливати на суспільні процеси; небайдужість до того, що відбувається навколо; довіра й уміння будувати конструктивні стосунки (Бойко, 2016). Отже, просоціальність як тип поведінки особистості передбачає соціальну взаємодію та характеризує особистість як соціальну зрілу, спроможну діяти на користь суспільних інтересів.

Як зазначає П. Бізін, сама просоціальність є незмінною рисою, необхідною для збалансованого існування індивіда в соціумі й рівень розвиненості може свідчити про певні особливості індивіда, схильності тощо. Як новоутворення просоціальність починає розвиватися із самого початку усвідомленого життя індивіда в соціумі, починаючи 3 ясел та закінчуючи етапом повного відсторонення від суспільства як такого (Бізін, 2019).

Підтвердження теоретичних тверджень - емпіричні дослідження, які проводили Дж. Твенге й ін. експериментальне дослідження щодо взаємозв'язку просоціальної поведінки та соціального відчуження. Так, науковці маніпулювали соціальним відчуженням, кажучи людям, що вони опиняться наодинці в подальшому житті. У результаті соціальне відчуження спричинило значне скорочення просоціальної поведінки. «Соціально вимкнені» люди пожертвували менше коштів у студентський фонд, не бажали добровільно подавати подальші дані експериментів у лабораторію, були менш корисними після невдач $\mathrm{i}$ менше співпрацювали в грі зі змішаним мотивом та з іншими студентами (Twenge et al, 2007).

Науковці Ш. Тейлор, Л. Піпл і Д. Сіре визначають поняття «допомагаючої поведінки» через соціальну поведінку: «Необхідність підкреслення просоціального характеру допомоги дійсно існує. Адже допомога може мати й антисоціальний характер (допомогти втекти зло- 
чинцю 3 в'язниці, украсти гроші та ін.)» (Пипло, Тейлор, \& Сире, 2003). В. Занде визначає соціальну поведінку як дії, що приносять користь іншим людям, а також способи реагування на людей, котрі проявляють симпатію, співпрацю, допомогу, сприяння, альтруїзм (Zanden, 1987).

Із метою з'ясування сутності й основних характеристик просоціальної поведінки, звернемося до визначення цього поняття.

Просоціальна поведінка - це поведінка, спрямована на допомогу, благо іншій людині без власної вигоди собі. За прояву такої поведінки люди керуються зовнішньою або внутрішньою мотивацією. При зовнішній мотивації людина прагне бути прикладом для наслідування, отримати якусь матеріальну винагороду, розширення кола спілкування або ввійти до певної групи. За внутрішньої мотивації людина прагне отримати визнання, ріст самоповаги, зміцнити почуття власної гідності та впевненості в собі (Вальоса, 2019).

Р. Роше Олівар вважає просоціальними всі ті типи поведінки, «які сприяють іншим особам, групам чи соціальним цілям і збільшують можливість породження позитивної якісної та солідарної взаємності в наступних міжособистісних чи соціальних стосунках, зберігаючи ідентичність, творчість й ініціативність задіяних індивідуумів чи груп» (Roche-Olivar, 1997).

Г. Іващенко визначає просоціальність як вчинки, спрямовані на благо іншої людини (при цьому в того, хто допомагає, є вибір, здійснювати їх чи ні (Иващенко, 2002)), В. Кім - як дії з надання допомоги (допомагаюча поведінка) (Ким, 1984).

О. Ігнацька просоціальну спрямованість особистості трактує як інтегральну властивість, що містить у собі всі прояви соціальної людської природи: потреби, бажання, потяги, установки, інтереси, схильності, ідеали, переконання, цінності, світогляд, життєві цілі. Також просоціальна спрямованість особистості трактується як стійка домінуюча ціннісно-мотиваційна система, що відображає глибинні смислові структури особистості, уключаючи світогляд людини й таке іiі ставлення до дійсності, як орієнтованість на благо інших людей без очікування отримати зовнішню винагороду. Просоціальний розвиток особистості відбувається через емоційне ставлення до іншого (Игнацкая, 2008).

Як зазначають К. Бетсон, А. Пауелл, просоціальна поведінка охоплює широкий спектр дій, спрямованих на користь однієї чи де- 
кількох людей, окрім себе. Такими діями є допомога, заспокоєння, обмін та співпраця. Альтруїзм - це мотивація до підвищення добробуту іншої людини; це протиставлення егоїзму, мотивації до підвищення власного добробуту. Між просоціальною поведінкою й альтруїзмом немає одноосібної відповідності. Просоціальну поведінку не потрібно мотивувати альтруїзмом; альтруїстична мотивація не повинна виробляти просоціальну поведінку (Batson, Powell, 2003).

Науковець Р. Никербокер щодо цієї проблеми зазначає, що просоціальність й альтруїзм - це насправді два різні поняття. Просоціальна поведінка належить до структури діяльності, тоді як альтруїзм - це мотивація допомагати іншим із чистої поваги до їхніх потреб, а не для того, щоб ця дія стала корисною тому, хто допомагає. Відомий приклад альтруїзму - це коли людина робить анонімне пожертвування людині, групі чи установі без будь-якого визнання, політичного чи економічного виграшу; тут пожертвування - це просоціальна дія, а альтруїзм - це те, що мотивує виконавця до дії. Отже, альтруїзм є «чистим» мотивовом просоціальної поведінки (Knickerbocker, 2003).

Р. Бенабу й Дж. Тіроль - розробники теорії просоціальної поведінки, яка поєднує неоднорідність в індивідуальному альтруїзмі та жадібності з турботою про соціальну репутацію або самоповагу. Нагороди чи покарання (будь-які матеріальні чи образні) викликають сумніви в справжньому мотиві, за якого робляться добрі вчинки, і цей «ефект перевиконання» може викликати часткове або навіть чисте витіснення просоціальної поведінки зовнішніми стимулами (Bénabou, Tirole, 2006). Отже, просоціальна поведінка, незважаючи на те, що покликана приносити користь іншим людям чи соціальним спільнотам, передбачає вигоду (зовнішню чи внутрішню) для того, хто допомагає.

Окрім визначення сутності, типів і взаємозв'язку понять «просоціальність» та «альтруїзм», актуальним у психологічній думці $\epsilon$ дослідження мотивів просоціальної поведінки особистості. До основних із них О. Гірченко, О. Буковська відносять моральний обов'язок, моральне співчуття, релігійні й морально-етичні (милосердя, патріотизм, альтруїзм) мотиви та особисте ставлення, яке проявляється, як благодійна моральна установка (особисте знання проблем людей, котрі потребують допомоги, розуміння необхідності підтримки держави у сфері освіти, науки, культури) (Гірченко, Буковська, 2019).

Дослідники Д. Поепсел і Д. Шроедер у книзі «Introduction to Psychology» зазначають, що існує декілька теорій, котрі пояснюють, 
які типи мотивів впливають на вчинення просоціальних дій (Poepsel \& Schroeder, 2018). Модель полегшення негативного стану (Cialdini, Darby, \& Vincent, 1973; Cialdini, Kenrick, \& Baumann, 1982) дає змогу припустити, що люди іноді допомагають, щоб почувати себе краще. Щоразу, коли нам стає сумно, ми можемо використовувати допомогу комусь іншому як позитивний підйом настрою або щоб відчувати себе щасливішим.

Модель витрат та винагороди - це додатковий спосіб зрозуміти, чому люди допомагають один одному (Piliavin, Dovidio, Gaertner, \& Clark, 1981). Ця модель фокусується на неприязних почуттях, викликаних баченням того, хто потребує допомоги. Коли ми бачимо когось, хто певним чином страждає (наприклад поранений, бездомний, голодний), ми по-справжньому відчуваємо симпатичне збудження, яке $\epsilon$ неприємним, і ми мотивовані усунути цей неприязний стан. Один зі способів зробити це - допомогти особі, котра цього потребує. Усуваючи біль жертви, ми усуваємо власне неприязне збудження. Допомога - це ефективний спосіб полегшити власний дискомфорт.

С. Бетсон запропонував емпатійно-альтруїстичну модель для пояснення альтруїстично-мотивованої допомоги, за якої помічник не очікує жодної вигоди. Відповідно до цієї моделі, ключовим для альтруїзму є співпереживання жертві, тобто уявлення себе на її місці (Batson, 2011).

Особливо цінними в розробці теорій мотивації просоціальних дій $\epsilon$ останні емпіричні дослідження. Так, Н. Кляйн зазначає, що пошук сенсу в житті - це основна особиста потреба, а мотивування просоціальної поведінки - фундаментальна суспільна потреба. Науковець перевірив, чи, допомогаючи іншим людям, можна збільшити власне уявлення про сенс життя. Дані з національно-репрезентативного набору даних та двох експериментів підтвердили цю гіпотезу. Учасники, які займалися просоціальною поведінкою, добровільно працювали й витрачали гроші на користь іншим, повідомили, що мають більше сенсу у своєму житті. Учасники, котрі витратили гроші на користь інших людей, відчували вищу особисту цінність та самооцінку. Це опосередковувало вплив просоціальної поведінки на осмисленість. Такі результати приєднуються до інших висновків, що дають змогу припустити, що стимули для допомоги іншим не обов'язково залежать від перспективи взаємності інших. Зазначено, що просоціальну поведінку можна стимулювати за допомогою психологічних переваг (Klein, 2017). 
Отже, дослідження мотивів просоціальної поведінки дає підставу робити висновки про можливості іiі розвитку та використання у власних цілях. Дж. К. Вівег досліджував, як лідери можуть виховувати доброзичливу культуру у своїх організаціях, заохочуючи працівників проявляти альтруїзм і просоціальну поведінку. Зокрема, науковець вивчав вплив просоціальної поведінки на організаційну культуру (Vieweg, 2018).

Дослідження, що проводилося Л. Акніним та ін., спиралося на твердження, що позитивні емоційні стани слугують спонуканням до позитивного досвіду та заохочують до просоціальної поведінки в майбутньому. Учені доводять, що позитивні почуття сприяють i винагороджують просоціальну поведінку протягом усього розвитку як у дітей, так і в дорослих. За висновками науковців, різні позитивні стани можуть спонукати просоціальну поведінку, а також просоціальна дія приводить до позитивних станів. Учені також розглядають можливість позитивного циклу зворотного зв'язку, у якому емоційна винагорода сприяє наданій просоціальності (Aknin, Van de Vondervoort \& Hamlin, 2018).

Попередні дослідження групи науковців на чолі з Ш. Дінг показали, що моральне судження, моральне піднесення й моральна ідентичність сприяють просоціальній поведінці. Множинні регресивні результати засвідчили, що моральне піднесення опосередковує вплив морального судження на просоціальну поведінку, а моральна ідентичність модерувала це посередництво шляхом взаємодії з моральним піднесенням (Ding et al., 2018).

Висновки. Аналіз теоретичних й емпіричних досліджень із порушеної теми дав підставу зробити висновок, що основною характеристикою просоціальної поведінки є іiі соціальна адаптованість, що виявляється у виконанні дій на благо інших. Просоціальна поведінка забезпечує розвиток суспільства, а також $є$ ефективним способом впливу та управління соціальними масами. Однією з найбільш нерозв'язаних проблем просоціальної поведінки $є$ вивчення мотивів, котрі спонукають особистість виконувати допоміжні дії.

На основі проаналізованих праць визначено, що існують три групи мотивів здійснення просоціальної поведінки. До першої можемо віднести альтруїстичні мотиви (реалізація просоціальної дії на благо інших без отримання вигоди, так звана «чиста допомога»). До другої групи належать егоїстичні мотиви, тобто ті, що передбачають вигоду 
для того, хто допомагає. Ними можуть бути внутрішні мотиви: мотив усунення психологічного дискомфорту, мотив отримання позитивних емоцій, мотиви самозаохочення й самоповаги тощо; та зовнішні мотиви, наприклад мотив соціального визнання. До третьої групи відносимо соціальні мотиви, тобто ті, які є загальноприйнятими в суспільстві й певним чином створюють певний соціальний тиск щодо виконання просоціальних дій. Це релігійні та морально-етичні (милосердя, патріотизм) мотиви.

Перспективами подальших досліджень є відбір та обгрунтування психодіагностичного інструментарію стратегії просоціальної поведінки «Допомога іншому» підлітків в умовах інклюзивного навчання.

\section{Лiтература}

1. Aknin, L. B., Van de Vondervoort, J. W., \& Hamlin, J. K. (2018). Positive feelings reward and promote prosocial behavior. Current opinion in psychology, 20, $55-59$.

2. Batson, C. D. (2011). Altruism in humans. New York, NY: Oxford University Press.

3. Batson, C. D., \& Powell, A. A. (2003). Altruism and prosocial behavior. Handbook of psychology, 463-484.

4. Bénabou, R., \& Tirole, J. (2006). Incentives and prosocial behavior. American economic review, 96(5), 1652-1678.

5. Cialdini, R. B., Darby, B. K. \& Vincent, J. E. (1973). Transgression and altruism: A case for hedonism. Journal of Experimental Social Psychology, 9, 502-516.

6. Cialdini, R. B., Kenrick, D. T., \& Baumann, D. J. (1982). Effects of mood on prosocial behavior in children and adults. In N. Eisenberg (Ed.), The development of prosocial behavior. New York, NY: Academic Press, 339-359.

7. Ding, W., Shao, Y., Sun, B., Xie, R., Li, W. and Wang, X. (2018). How Can Prosocial Behavior Be Motivated? The Different Roles of Moral Judgment, Moral Elevation, and Moral Identity Among the Young Chinese. Front. Psychol., 9, 814 p. doi: 10.3389/fpsyg.2018.00814

8. Eisenberg, N., \& Spinrad, T. L. (2014). Multidimensionality of prosocial behavior: Rethinking the conceptualization and development of prosocial behavior. In L. M. Padilla-Walker \& G. Carlo (Eds.), Prosocial development: A multidimensional approach. Oxford University Press, 17-39. https://doi.org/ 10.1093/acprof:oso/9780199964772.003.0002

9. Klein, N. (2017). Prosocial behavior increases perceptions of meaning in life. The Journal of Positive Psychology, 12(4), 354-361.

10. Knickerbocker, R. L. (2003). Prosocial behavior. Center on Philanthropy at Indiana University, 1-3.

11. Piliavin, J. A., Dovidio, J. F., Gaertner, S. L., \& Clark, R. D., III (1981). Emergency intervention. New York, NY: Academic Press. 
12. Poepsel, D. L., \& Schroeder, D. A. (2018). Helping and Prosocial Behavior. HKU PSYC2020, 140. Available at: https://opentextbc.ca/introductiontopsychology/

13. Roche-Olivar, R. (1997). Optimizatione prosociale: basi teoriche, obiettivi e strumenti. La condotta prosociale: basi teoriche e metodologie d'intervento. Bulzoni Editore, 15-37.

14. Twenge, J. M., Baumeister, R. F., DeWall, C. N., Ciarocco, N. J., \& Bartels, J. M. (2007). Social exclusion decreases prosocial behavior. Journal of personality and social psychology, 92(1), 56.

15. Vieweg, J. C. (2018). Prosocial behaviors: Their motivations and impacts on organizational culture. The Journal of Values-Based Leadership, 11(2), 12.

16. Zanden, V. \& James, W. (1987). Social psychology. 4 th ed. N. Y.: McGraw-Hill Inc., 646 p.

17. Бізін, П. С. (2019). Просоціальність: поняття та історія досліджень. Актуальні проблеми особистісного зростання. Збірник наукових праць [за матеріалами Всеукраїнської науково-практичної конференції для молодих учених (м. Житомир, 19 квітня 2019 року)]. Житомир, Вид-во ЖДУ імені Івана Франка. URL: http://eprints.zu.edu.ua/29372/1/\%D0\%A2\%D0\%B5\%D0\%B7\%D0\% B8\%20\%D 0\%91\%D1\%96\%D0\%B7\%D1\%96\%D0\%BD.pdf

18. Бойко, О. П. (2016). Просоціальність: суть і потенціал у соціально-педагогічній діяльності. Соціальна робота в Украӥні: теорія $і$ практика, 1-2, 140-149. URL: http://nbuv.gov.ua/UJRN/srutip_2016_1-2_17

19. Вальоса, М. П. (2017). Психологічна сутність просоціальної поведінки особистості. Економіка інноваційної діяльності підприємств. Педагогіка та психологія, мова та культура, 737-738. URL: https://er.knutd.edu.ua/bitstream/ 123456789/8513/1/NRMSE2017_V3_P737-738.pdf

20. Войтко, В. І. (ред.) (1982). Психологічний словник. Київ: Вища шк., 215 с.

21. Гірченко, О. Л. \& Буковська, О. О. (2019). Просоціальна спрямованість та поведінка особистості. Актуальні проблеми психології, 7 (47), 120-129.

22. Иващенко, Г. М. (2002). Восстановление сочиального статуса безнадзорныхх детей. Москва: ГосНИИ семьи и воспитания, $128 \mathrm{c.}$

23. Игнацкая, О. (2008). Особенности изучения компонентов просоциальной направленности личности старшеклассников. Психологический журнал, 4, 68-73.

24. Ким, В. Е. (1984). Диагностика альтруистических установок личности. (Автореф. дис. канд. психол. наук: 19.00.01). Москва, 20 с.

25. Кондаков, И. М. (2007). Психологический словарь. Москва: «ОЛМА Медиа Групп», «ОЛМА Пресс Образование», 512 с.

26. Пипло, Л., Тейлор, Ш., \& Сире, Д. (2003). Социальная психология, 10-е изд. Санкт-Петербург: Питер, 786 с.

\section{References}

1. Aknin, L. B., Van de Vondervoort, J. W., \& Hamlin, J. K. (2018). Positive feelings reward and promote prosocial behavior. Current opinion in psychology, 20, $55-59$. 
2. Batson, C. D. (2011). Altruism in humans. New York, NY: Oxford University Press.

3. Batson, C. D., \& Powell, A. A. (2003). Altruism and prosocial behavior. Handbook of psychology, 463-484.

4. Bénabou, R., \& Tirole, J. (2006). Incentives and prosocial behavior. American economic review, 96(5), 1652-1678.

5. Cialdini, R. B., Darby, B. K. \& Vincent, J. E. (1973). Transgression and altruism: A case for hedonism. Journal of Experimental Social Psychology, 9, 502-516.

6. Cialdini, R. B., Kenrick, D. T., \& Baumann, D. J. (1982). Effects of mood on prosocial behavior in children and adults. In N. Eisenberg (Ed.), The development of prosocial behavior. New York, NY: Academic Press, 339-359.

7. Ding, W., Shao, Y., Sun, B., Xie, R., Li, W. and Wang, X. (2018). How Can Prosocial Behavior Be Motivated? The Different Roles of Moral Judgment, Moral Elevation, and Moral Identity Among the Young Chinese. Front. Psychol., 9, 814 p. doi: 10.3389/fpsyg.2018.00814

8. Eisenberg, N., \& Spinrad, T. L. (2014). Multidimensionality of prosocial behavior: Rethinking the conceptualization and development of prosocial behavior. In L. M. Padilla-Walker \& G. Carlo (Eds.), Prosocial development: A multidimensional approach. Oxford University Press, 17-39. https://doi.org/ 10.1093/acprof:oso/9780199964772.003.0002

9. Klein, N. (2017). Prosocial behavior increases perceptions of meaning in life. The Journal of Positive Psychology, 12(4), 354-361.

10. Knickerbocker, R. L. (2003). Prosocial behavior. Center on Philanthropy at Indiana University, 1-3.

11. Piliavin, J. A., Dovidio, J. F., Gaertner, S. L., \& Clark, R. D., III (1981). Emergency intervention. New York, NY: Academic Press.

12. Poepsel, D. L., \& Schroeder, D. A. (2018). Helping and Prosocial Behavior. $H K U$ PSYC2020, 140. Available at: https://opentextbc.ca/introductiontopsychology/

13. Roche-Olivar, R. (1997). Optimizatione prosociale: basi teoriche, obiettivi e strumenti. La condotta prosociale: basi teoriche e metodologie d'intervento. Bulzoni Editore, 15-37.

14. Twenge, J. M., Baumeister, R. F., DeWall, C. N., Ciarocco, N. J., \& Bartels, J. M. (2007). Social exclusion decreases prosocial behavior. Journal of personality and social psychology, 92(1), $56 \mathrm{p}$.

15. Vieweg, J. C. (2018). Prosocial behaviors: Their motivations and impacts on organizational culture. The Journal of Values-Based Leadership, 11(2), 12.

16. Zanden, V. \& James, W. (1987). Social psychology. 4 th ed. N.Y.: McGraw-Hill Inc., 646 p.

17. Bizin, P. S. (2019). Prosotsialnist: poniattia ta istoriia doslidzhen [Prosociality: the concept and history of research]. Aktualni problemy osobystisnoho zrostannia. Zbirnyk naukovykh prats [za materialamy Vseukrainskoi naukovopraktychnoi konferentsii dlia molodykh uchenykh (m. Zhytomyr, 19 kvitnia 
2019 roku)]. Zhytomyr, Vyd-vo ZhDU imeni Ivana Franka.URL: http://eprints.zu. edu.ua/29372/1/\%D0\%A2\%D0\%B5\%D0\%B7\%D0\%B8\%20\%D

0\%91\%D1\%96\%D0\%B7\%D1\%96\%D0\%BD.pdf (in Ukrainian).

18. Boiko, O. P. (2016). Prosotsialnist: sut i potentsial u sotsialno-pedahohichnii diialnosti [Prosociality: the essence and potential in socio-pedagogical activities]. Sotsialna robota v Ukraini: teoriia i praktyka, 1-2, 140-149. URL: http://nbuv.gov. ua/UJRN/srutip_2016_1-2_17 (in Ukrainian).

19. Valosa, M. P. (2017). Psykholohichna sutnist prosotsialnoi povedinky osobystosti [Psychological essence of prosocial behavior of the individual]. Ekonomika innovatsiinoi diialnosti pidpryiemstv. Pedahohika ta psykholohiia, mova ta kultura, 737-738. URL: https://er.knutd.edu.ua/bitstream/123456789/8513/ 1/NRMSE2017_V3_P737-738.pdf (in Ukrainian].

20. Voitko, V. I. (Red.). (1982). Psykholohichnyi slovnyk [Psychological dictionary]. Kyiv: Vyshcha shkola, 215 p. (in Ukrainian).

21. Hirchenko, O. L. \& Bukovska, O. O. (2019). Prosotsialna spriamovanist ta povedinka osobystosti [Prosocial orientation and personality behavior]. Aktualni problemy psykholohii, 7 (47),120-129 (in Ukrainian).

22. Ivashhenko, G. M. (2002). Vosstanovlenie social'nogo statusa beznadzornyh detej [Restoration of the social status of neglected children]. Moskva: GosNII sem'i i vospitanija, 128 p. (in Russian).

23. Ignackaja, O. (2008). Osobennosti izuchenija komponentov prosocial'noj napravlennosti lichnosti starsheklassnikov [Features of the study of the components of the prosocial orientation of the personality of high school students]. Psihologicheskij zhurnal, 4, 68-73 (in Russian).

24. Kim, V. E. (1984). Diagnostika al'truisticheskih ustanovok lichnosti [Diagnosis of altruistic personality attitudes]. (Avtoref. dis. kand. psihol. nauk: 19.00.01). Moskva, 20 p. (in Russian).

25. Kondakov, I. M. (2007). Psihologicheskij slovar' [Psychological dictionary]. Moskva: «OLMA Media Grupp», «OLMA Press Obrazovanie», 512 p. (in Russian).

26. Piplo, L., Tejlor, Sh., \& Sire, D. (2003). Social'naja psihologija [Social Psychology]. 10-e izd. SP b: Piter, 786 p. (in Russian).

Received: 09.02.2020

Accepted: 25.02.2020 